\title{
Detection of the omicron variant in international travellers and their family contacts in India
}

\section{Authors:}

1* Varsha A. Potdar* Ph.D, Pragya D. Yadav*, Ph.D, ${ }^{1}$ Kavita Lole Ph.D, ${ }^{1}$ Sarah Cherian Ph.D, ${ }^{2}$ Jayanti Shastri MD, ${ }^{3}$ Bharati Malhotra MD, ${ }^{1}$ Sumit Bharadwaj MD, ${ }^{4}$ Alpana Razdan, Ph.D, ${ }^{1}$ M L Choudhary Ph.D, ${ }^{5}$ Nivedita Gupta, Ph.D , ${ }^{1}$ Priya Abraham ${ }^{\#}$ MD, NIC team , Bioinformatics team, BSL4 team ,The Indian SARS-CoV-2 Genomics Consortium $\left(\right.$ INSACOG) ${ }^{\$}$

NIC Team: Ashwini Ramdasi, Mousmy Das, Deepika Chaudhary, Sheetal Jadhav,Krutika Iyangar, Kalpita Korobu, Pooja Shinde, Pratikta Pawar, Gayatri Divekar, Nikhil Munne, Vishal Awtade, Rohan Ghuge.

BSL 4 team: Anita M. Shete, Ph.D, Rima R. Sahay, MD, Deepak Y. Patil, Ph.D, Dimpal A. Nyayanit, Ph.D, Abhinendra Kumar, Ph.D

Bioinformatics Team: Atul walimbe, Santoshkumar Jadhav, Amol Gaykwad, Rama Kulkarni, Pooja waghchoure

\section{Affiliations:}

${ }^{1}$ Indian Council of Medical Research-National Institute of Virology, Pune, Maharashtra, India, Pin-411021

${ }^{2}$ Kasturba Hospital for infectious Diseases, Sane Guruji Marg, Chichpokli, Mumbai Maharashtra 400011

${ }^{3}$ Sawai Man Singh Medical College, Jaipur - 302004.

${ }^{4}$ Genestrings Diagnostic Centre Pvt. Ltd., 3, MMTC, Geetanjali Enclave, New Delhi Pin 110017

Indian Council of Medical Research, V. Ramalingaswami Bhawan, P.O. Box No. 4911, Ansari Nagar, New Delhi, India Pin-110029

\section{*Equal authors}

\section{\# Corresponding author}

Dr Priya Abraham, Director

Indian Council of Medical Research-National Institute of Virology, 
medRxiv preprint doi: https://doi.org/10.1101/2021.12.27.21268429; this version posted December 30, 2021. The copyright holder for this preprint (which was not certified by peer review) is the author/funder, who has granted medRxiv a license to display the preprint in perpetuity. All rights reserved. No reuse allowed without permission.

20 A Dr Ambedkar road

Pune 411001

Keywords: SARS-CoV-2; Variant of concern; Omicron, International travellers, India 
medRxiv preprint doi: https://doi.org/10.1101/2021.12.27.21268429; this version posted December 30, 2021. The copyright holder for this preprint (which was not certified by peer review) is the author/funder, who has granted medRxiv a license to display the preprint in perpetuity. All rights reserved. No reuse allowed without permission.

\section{Highlights}

With the emergence of the Variant of Concern, omicron (B.1.1.529), India has enhanced genomic surveillance in international travellers. The omicron variant was detected in 59 cases from different States; 40 from Maharashtra, 17 from Rajasthan and one each from Gujrat and Tamil Nadu. The positive cases and their contacts were asymptomatic and genomic surveillance could identify two clusters, one from Maharashtra and another from Rajasthan. 
medRxiv preprint doi: https://doi.org/10.1101/2021.12.27.21268429; this version posted December 30, 2021. The copyright holder for this

The first confirmed case of the new SARS-CoV-2 Variant of Concern (VOC) was reported on November 24th, 2021 [1]. The WHO's Technical Advisory Group on SARSCoV-2 Virus Evolution designated the Pangolin lineage B.1.1.529; Nextstrain 21K (omicron) as VOC on November 26. [1]. When compared to the Wuhan virus, the variant spike protein comprises 30 amino acid changes, three small deletions and one short insertion, 15 in the receptor binding domain (residues 319-541). [2] Its genome also features a number of changes and deletions. The furin cleavage site contains three mutations in this variant that could further increase SARS-CoV-2 infectivity [3.].

Many of the sequences submitted by South Africa, Australia, and Canada lack the identifying mutations of B.1.1.529 (omicron). To integrate all of these variations in the B.1.1.529 lineage, two sub-lineages were identified: 21K (omicron) or BA.1 and 21L (BA.2). 21K (omicron) is of concern because to its high frequency of spike gene mutations. The spike protein of the B.1.1.529 parent lineage viz. 21M (omicron), has only 21 amino-acid mutations, with the BA.1 (omicron) sub-lineage having 129 distinct mutations and BA.2 having 6 mutations (T19I, V213G, S371F, T376A, D405N, and R408S) and a 9 nucleotide loss at position 21633-21641 leading to A27S/L24S mutation. The BA.2 lacks the S: H69- and S: V70- deletion that causes "S-gene drop out" or S gene target failure (SGTF) in TaqPath RT PCR assays that monitors BA.1 (omicron) [4].

As of 21 December 202178 countries shared 18,264 Omicron genome sequences with GISAID [5, 6]. The Indian government revised its overseas entry criteria after reports of the new SARS-CoV-2 variant (B.1.1.529; omicron). The COVID-19 test protocol requires that samples from travellers from risk nations be sent to the Indian SARS-CoV-2 Consortium on Genomics (INSACOG) network for genetic testing. The ICMR-National Institute of Virology, Pune, being a part of the network, thus sequenced clinical specimens from overseas travellers to India. Laboratories under INSACOG also shared the raw sequencing data with ICMR-NIV, Pune, which analysed and reported the sequencing results. All referenced samples during November-December 2021 were tested for SARS-CoV-2 RT-PCR. Previously published techniques (Ref 7, 8) were used to sequence the genome using the Oxford Nanopore Minion, Ion Torrent S5 and Illumina MiniSeq NGS platforms. The MagMAXTM Viral Pathogen Nucleic Acid Isolation Kit was used to isolate RNA from viral infections (Thermo Fisher Scientific, USA). Library creation and quantification followed the sequencing platform. The midnight technique 
medRxiv preprint doi: https://doi.org/10.1101/2021.12.27.21268429; this version posted December 30, 2021. The copyright holder for this

was employed for Oxpford Nanopore. Commander S/w version 1.6 .2 was used to sequence the complete genome. Wuhan-HU-1 was used for reference-based genome assembly. The sequences were submitted to GISAID.

A total, 1902 samples were referred for omicron testing till December 17th, 2021. 1630 came from overseas travellers, while 272 came from friends and family contacts. The states of Maharashtra, Gujarat, Tamil Nadu, and Port Blair referred the samples, with majority from Maharashtra. The referred cases had median age of 38 years (IQR 28-53 years). The referred sample comprised 823 females (43.2\%). RRT-PCR detected SARS CoV-2 in 177 samples. With the procedure described above, 111 samples were processed for whole genome sequencing (WGS). Additionally, 164 samples were processed for S gene detection using the Taq Path assay and 116 samples had S gene detection, whereas 48 had SGTF. Among 116 S gene detected cases; 6 samples were detected as omicron, whereas among 48 SGTF, 22 were omicron.

We detected $29(26.1 \%)$ as the omicron variant, 73 (65.8\%) as delta and delta sub-lineages, 4 (3.6\%) as other lineages and 5 (4.5\%) were sequencing failures. Additionally, 30 omicron cases were identified from the sequencing analysis of raw data submitted by SMS Jaipur and Public health lab, Chennai. To summarise, 33 (55.9\%) overseas travellers and 26 (44.1\%) contacts reported 59 omicron incidents. The novel VOC omicron was phylogenetically analysed along with known VOCs alpha, beta, gamma, and delta, randomly selected from GISAID, preferably from India

The final dataset included 55 ICMR-NIV sequences, 7 omicron variants reported from India, and 20 VOCs. MAFFT version 7.45 was used for multiple sequence alignment. The Maximum Composite Likelihood distance approach was used to build a neighbour-joining (N) tree in MEGA v6 (Ref 9, 10). As seen in Fig. 1, all the sequences were of omicron BA.1 lineage except for a single sequence of lineage BA.2.

This study discovered two distinct family clusters in which overseas returnees infected close family members (cluster-1 and cluster-2). In cluster-1, eight members of family were found. Three were index cases, while the others were contacts. The index case returned from Nigeria after testing negative for COVID-19 at Nigeria airport. Later, family members in India tested positive for omicron (Figure-2a). The whole family reported a COVID-19 infection history in August 2020. 
medRxiv preprint doi: https://doi.org/10.1101/2021.12.27.21268429; this version posted December 30, 2021. The copyright holder for this

The cluster-2, in which five members of a family were infected within a fourhour period of brief exposure by the index cases. Index cases were tested RT-PCR negative at Johannesburg airport (Figure-2b) In September 2020, all these index cases and family members had COVID-19.

Omicron was readily spread through close contact, with a three-to-six-day incubation period. Seventeen of the omicron cases in the family cluster were vaccinated against COVID-19, while one adult was unvaccinated. None of the afflicted family members required medical assistance or hospitalisation. It was confirmed that all the contact cases were SARS CoV-2 re-infections.

Several laboratories have reported the use of S gene detection as a screening tool for identification of probable omicron variants. However, the SGTF is also reported in other VOCs like alpha; hence cautioning the use of S gene target. Our study showed $50 \%$ of cases of SGTF had the omicron variant and that this test can thus be used as a flag for this variant where sequencing confirmation is pending. In this article, two omicroninfected family clusters are presented. WGS confirmed omicron infection in members of this family cluster. It was discovered incidentally under the screening programme for foreign returnees and their close contacts. Fortunately, the three symptomatic family members recovered completely. The INSACOG hub at Pune further sequenced 1665 community samples during November from Maharashtra and no omicron variant was detected. As of now, omicron positivity is reported only among international travellers and their contacts. Family members of persons who have been diagnosed with COVID19 should be closely monitored and tested for virus infection, even if they exhibit no symptoms.

\section{Ethical approval}

The study was approved by the Institutional Biosafety Committee and Institutional Human Ethics Committee of ICMR-NIV, Pune, India under the project titled 'Molecular epidemiological analysis of SARS-COV-2 circulating in different regions of India'.

\section{Author contributions}

VAP, PDY, SC, KL, JS, BM, AR accessed and verified the data. VAP, PDY, SC, SB contributed to the analysis and manuscript preparation. VAP was the study coordinator, PA, MLC, 
medRxiv preprint doi: https://doi.org/10.1101/2021.12.27.21268429; this version posted December 30, 2021. The copyright holder for this preprint (which was not certified by peer review) is the author/funder, who has granted medRxiv a license to display the preprint in perpetuity. All rights reserved. No reuse allowed without permission.

$\mathrm{KL}$, SC reviewed the manuscript. VAP was responsible for overall supervision of the study and review of the final paper.

\section{Financial support \& sponsorship}

Financial support was provided by the Department of Health Research, Ministry of Health \& Family Welfare, New Delhi, to ICMR-National Institute of Virology, Pune

\section{Competing interests:}

No competing interest exists among the authors.

Acknowledgement: Dr Pradip Awate and State IDSP team. Mumbai Municipal Corporation, Pune Munciple Corporation and Pimpri Chinchwad Municipal Corporation for sample referral.

\section{References}


medRxiv preprint doi: https://doi.org/10.1101/2021.12.27.21268429; this version posted December 30, 2021. The copyright holder for this preprint (which was not certified by peer review) is the author/funder, who has granted medRxiv a license to display the preprint in perpetuity. All rights reserved. No reuse allowed without permission.

1. World Health Organization. Classification of Omicron (B.1.1.529): SARS-CoV-2 Variant of Concern. https://www.who.int/news/item/26-11-2021classification-of-omicron-(b.1.1.529)-sars-cov-2-variant-of-concern. Accessed on December 9, 2021.

2. E Callaway, Ewen. "Heavily mutated coronavirus variant puts scientists on alert". Nature. 2021; 600 (7887): 21. doi:10.1038/d41586-021-03552-w.

3. Shang Yu Gong, Debashree Chatterjee, Jonathan Richard, Jérémie Prévost, Alexandra Tauzin, Romain Gasser, Yuxia Bo, Dani Vézina, Guillaume Goyette, Gabrielle Gendron-Lepage, Halima Medjahed, Michel Roger, Marceline Côté, Andrés Finzi : Contribution of single mutations to selected SARS-CoV-2 emerging variants Spike antigenicity bioRxiv 2021.08.04.455140; doi: https://doi.org/10.1101/2021.08.04.455140

4. "The birth of Omicron: Did HIV play a role?". www.medicalnewstoday.com. 6 December 2021. Retrieved 11 December 2021.

5. Tracking of Variants. Omicron. https://www.gisaid.org/hcov19-variants/. Accessed on December 21, 2021.

6. World Health Organization. Classification of Omicron (B.1.1.529): SARS-CoV-2 Variant of Concern. https://www.who.int/news/item/26-11-2021-classificationof-omicron-(b.1.1.529)-sars-cov-2-variant-of-concern. Accessed on December 9, 2021.

7. Yadav PD, Potdar VA, Choudhary ML, Nyayanit DA, Agrawal M, Jadhav SM, et al. Full-genome sequences of the first two SARS-CoV-2 viruses from India. Indian J Med Res 2020; 151. doi: 10.4103/ijmr.IJMR_663_20.

8. Potdar V, Vipat V, Ramdasi A, Jadhav S, Pawar-Patil J, Walimbe A, Patil SS, Choudhury ML, Shastri J, Agrawal S, Pawar S, Lole K, Abraham P, Cherian S, IN. Phylogenetic classification of the whole-genome sequences of SARS-CoV-2 from India \& evolutionary trends. Indian J Med Res 2021;153:166-74

9. Katoh, Rozewicki, Yamada 2019 (Briefings in Bioinformatics 20:1160-1166). MAFFT online service: multiple sequence alignment, interactive sequence choice and visualization

10. Koichiro Tamura, Glen Stecher, Daniel Peterson, Alan Filipski, and Sudhir Kumar (2013) MEGA6: Molecular Evolutionary Genetics Analysis version 6.0. Molecular Biology and Evolution:30 2725-2729 
medRxiv preprint doi: https://doi.org/10.1101/2021.12.27.21268429; this version posted December 30, 2021. The copyright holder for this preprint (which was not certified by peer review) is the author/funder, who has granted medRxiv a license to display the preprint in perpetuity. All rights reserved. No reuse allowed without permission.

Fig. 1 Neighbor-Joining (NJ) tree of SARS CoV 2 depicting Variants of Concern (VOC) viz. Alpha, Beta, Gamma, Delta and Omicron (blue colour)

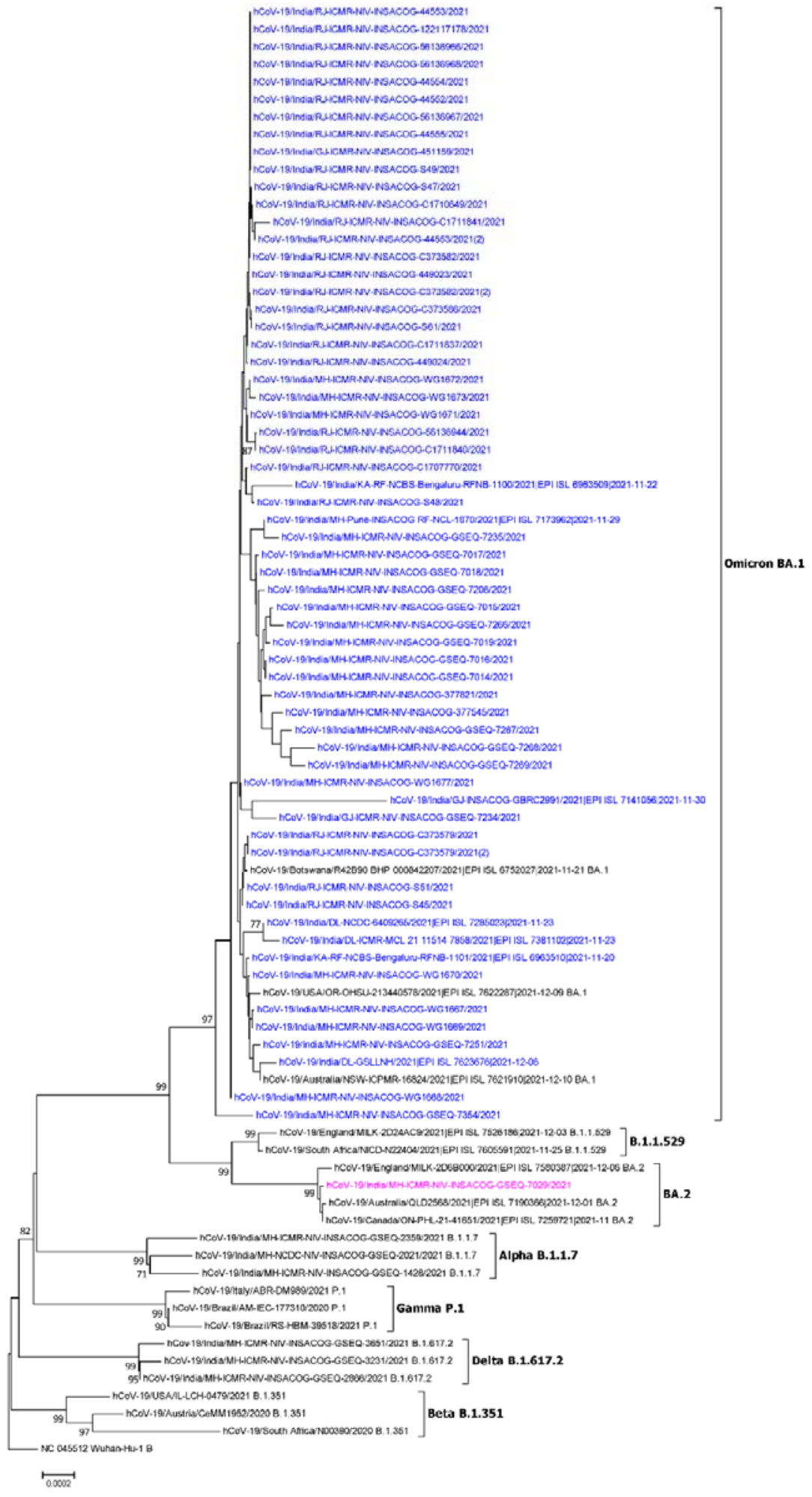


Figure-2aFamily cluster-1

Dates

Index case 1

(41-45 yr, symptomatic, Fully COVID-19 vaccinated)

Index case 2

( $11-15$ years, symptomatic)

Index case 3

(16-20 years, Asymptomatic, Fully COVID-19 vaccinated)

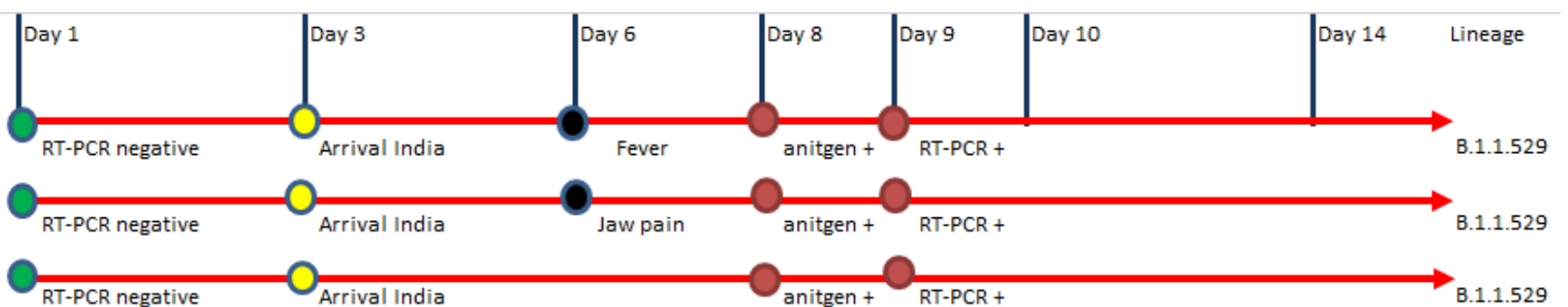

Family contact- 1

(41-45 years, Asymptomatic, Unvaccinated)

Family contact- 2

(6-10 years, Asymptomatic)

Family contact-3

(0-5 years, Symptomatic)

Family contact- 4

(71-75 years, Symptomatic, Fully COVID-19 vaccinated, Diabetis)

Family contact- 5

(66-70 years, Asymptomatic, Fully COVID-19 vaccinated Family contact- 6

(41-45 years, Asymptomatic, Fully CoVID-19 vaccinated)

Family contact-7

(3 years, Asymptomatic)

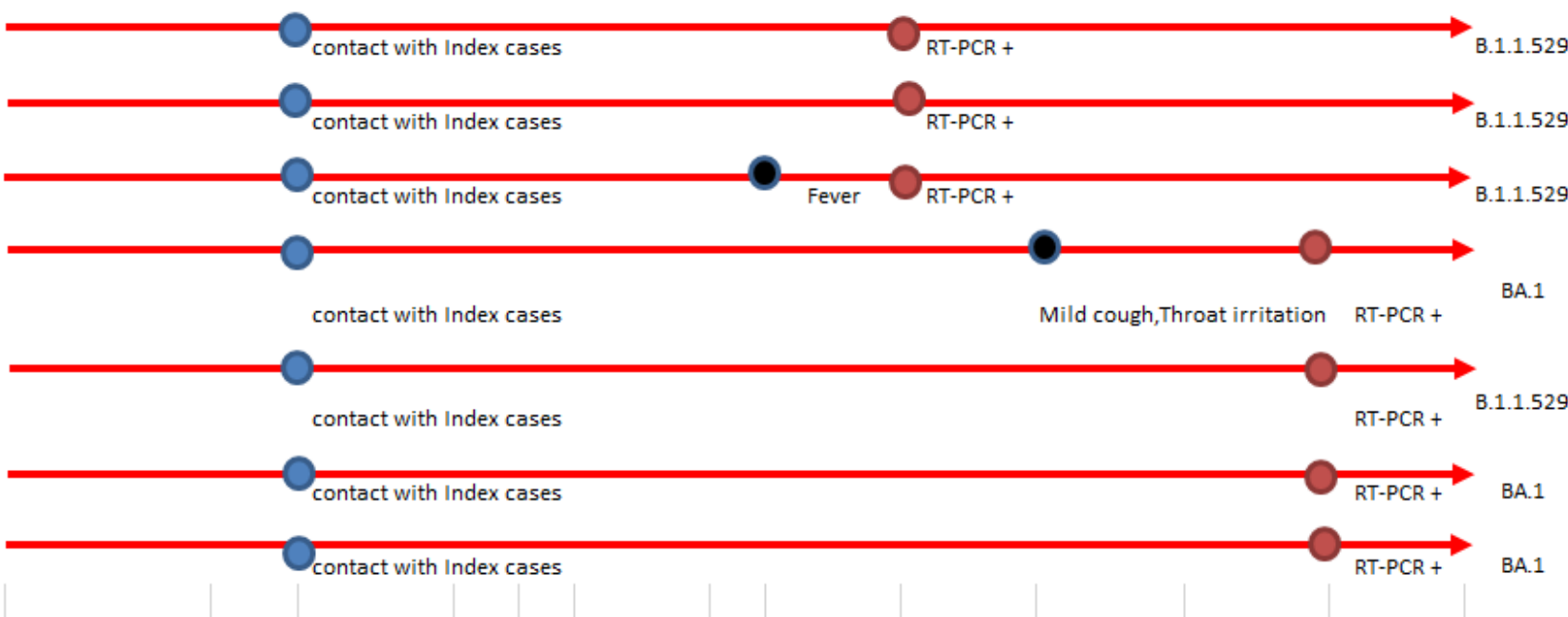


Figure-2b Family cluster-2

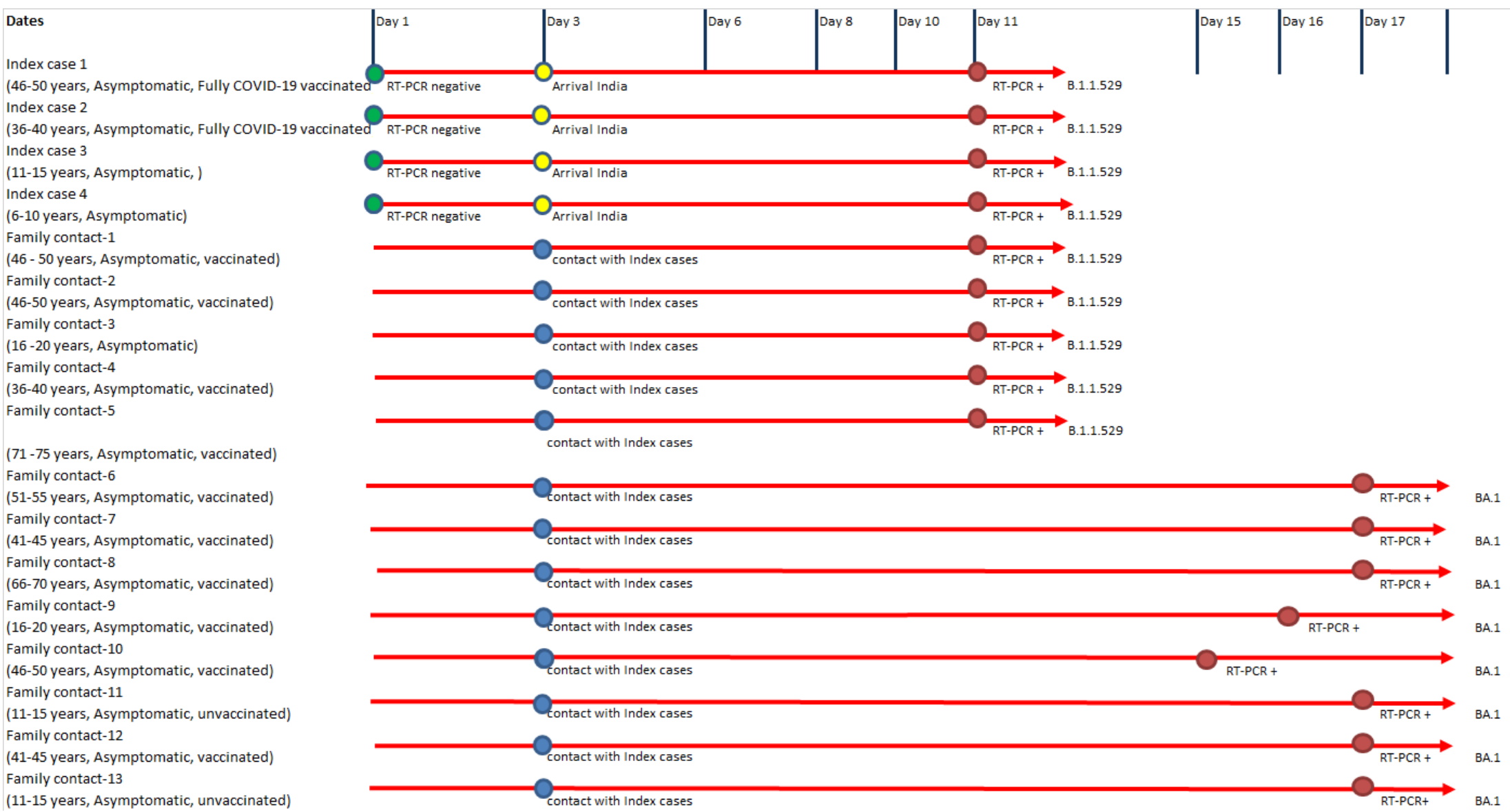


List of INSACOG Consortium Members

\begin{tabular}{|l|l|l|}
\hline NAME & AFFILIATION & EMAIL ID \\
\hline Anurag Agarwal & CSIR-Institute of Genomics and Integrative Biology (IGIB), Delhi & a.agrawal@igib.in \\
\hline $\begin{array}{l}\text { Vinay Nandicoori } \\
\text { Bharadwaj Tallapaka }\end{array}$ & $\begin{array}{l}\text { CSIR Centre for Cellular and } \\
\text { Molecular Biology }\end{array}$ & vinaykn@ccmb \\
\hline Divya Tej Sowpati & $\begin{array}{l}\text { CSIR Centre for Cellular and } \\
\text { Molecular Biology }\end{array}$ & karthikt@ccmb.res.in \\
\hline K Thangaraj & $\begin{array}{l}\text { Centre for DNA Fingerprinting } \\
\text { and Diagnostics }\end{array}$ & tej@ccmb.res.in \\
\hline Murali Dharan Bashyam & $\begin{array}{l}\text { Centre for DNA Fingerprinting } \\
\text { and Diagnostics }\end{array}$ & director@cdfd.org.in \\
\hline Ashwin Dalal & $\begin{array}{l}\text { Centre for DNA Fingerprinting } \\
\text { and Diagnostics }\end{array}$ & bashyam@cdfd.org.in \\
\hline Sridhar Sivasubbu & $\begin{array}{l}\text { CSIR Institute of Genomics and } \\
\text { Integrative Biology }\end{array}$ & sridhar@igib.in \\
\hline
\end{tabular}




\begin{tabular}{|c|c|c|}
\hline Vinod Scaria & $\begin{array}{l}\text { CSIR Institute of Genomics and } \\
\text { Integrative Biology }\end{array}$ & vinods@igib.in \\
\hline Ajay Parida & Institute of Life Sciences & drajayparida@gmail \\
\hline Sunil K Raghav & Institute of Life Sciences & sunilraghav@ils.res.in \\
\hline Punit Prasad & Institute of Life Sciences & punit@ils.res.in \\
\hline Apurva Sarin & $\begin{array}{l}\text { Institute For Stem Cell Science and Regenerative } \\
\text { Medicine/National Centre for Biological Sciences }\end{array}$ & sarina@instem.res.in \\
\hline Satyajit Mayor & $\begin{array}{l}\text { Institute For Stem Cell Science } \\
\text { and Regenerative } \\
\text { Medicine/National Centre for } \\
\text { Biological Sciences }\end{array}$ & mayor@ncbs.res.in \\
\hline Uma Ramakrishnan & $\begin{array}{l}\text { Institute For Stem Cell Science } \\
\text { and Regenerative } \\
\text { Medicine/National Centre for } \\
\text { Biological Sciences }\end{array}$ & uramakri@ncbs.res.in \\
\hline Dasaradhi Palakodeti & $\begin{array}{l}\text { Institute For Stem Cell Science } \\
\text { and Regenerative } \\
\text { Medicine/National Centre for } \\
\text { Biological Sciences }\end{array}$ & dasaradhip@instem.res.in \\
\hline $\begin{array}{l}\text { Aswin Sai } \\
\text { Narain Seshasayee }\end{array}$ & $\begin{array}{l}\text { Institute For Stem Cell Science } \\
\text { and Regenerative } \\
\text { Medicine/National Centre for } \\
\text { Biological Sciences }\end{array}$ & $\begin{array}{l}\text { aswin@ncbs.res.in } \\
18\end{array}$ \\
\hline Manoj Bhat & $\begin{array}{l}\text { National Centre For Cell } \\
\text { Science }\end{array}$ & manojkbhat@nccs.res.in \\
\hline Yogesh Shouche & $\begin{array}{l}\text { National Centre For Cell } \\
\text { Science }\end{array}$ & yogesh@nccs.res.in \\
\hline
\end{tabular}




\begin{tabular}{|c|c|c|}
\hline Sujeet Singh & National Centre for Disease Control & sujeet647@gmail.com \\
\hline Himanshu Chauhan & National Centre for Disease Control & himanshu.chauhan@nic.in \\
\hline Tanzin Dikid & National Centre for Disease Control & tanzindikid@gmail.com \\
\hline Saumitra Das & $\begin{array}{l}\text { National Institute of } \\
\text { Biomedical Genomics }\end{array}$ & sdas@nibmg.ac.in \\
\hline Arindam Maitra & $\begin{array}{l}\text { National Institute of } \\
\text { Biomedical Genomics }\end{array}$ & am1@nibmg.ac.in \\
\hline Sreedhar Chinnaswamy & $\begin{array}{l}\text { National Institute of } \\
\text { Biomedical Genomics }\end{array}$ & sc2@nibmg.ac.in \\
\hline Nidhan Kumar Biswas & $\begin{array}{l}\text { National Institute of } \\
\text { Biomedical Genomics }\end{array}$ & nkb1@nibmg.ac.in \\
\hline Anita Sudhir Desai & $\begin{array}{l}\text { National Institute of Mental } \\
\text { Health and Neuro Sciences }\end{array}$ & anitasdesai@gmail.com \\
\hline Chitra Pattabiraman & $\begin{array}{l}\text { National Institute of Mental } \\
\text { Health and Neuro Sciences }\end{array}$ & pattabiraman.chitra@gmail.com \\
\hline M. V. Manjunatha & $\begin{array}{l}\text { National Institute of Mental } \\
\text { Health and Neuro Sciences }\end{array}$ & manjuvswamy@gmail.com \\
\hline Reeta S Mani & $\begin{array}{l}\text { National Institute of Mental } \\
\text { Health and Neuro Sciences }\end{array}$ & drreeta@gmail.com \\
\hline
\end{tabular}


